\title{
Effect of Nauclea subdita (Korth.) Steud. leaf extract on hematological and histopathological changes in liver and kidney of striped catfish infected by Aeromonas hydrophila
}

\author{
Siti Aisiah ${ }^{1,2}$, Arief Prajitno ${ }^{3}$, Maftuch Maftuch ${ }^{3}$ and Ating Yuniarti ${ }^{3}$
}

1. Doctoral Program of Fisheries and Marine Sciences, Faculty of Fisheries and Marine Sciences, Brawijaya University, Malang, East Java 65145, Indonesia; 2. Department of Aquaculture, Faculty of Fisheries and Marine Sciences, Lambung Mangkurat University, Banjarbaru, South Kalimantan 70714, Indonesia; 3. Department of Aquaculture, Faculty of Fisheries and Marine Sciences, Brawijaya University, Malang, East Java 65145, Indonesia.

Corresponding author: Siti Aisiah, e-mail: sitiaisiah@ulm.ac.id

Co-authors: AP: ariefprajitno@ub.ac.id, MM: maftuch@ub.ac.id, AY: yuniarti_a2003@yahoo.com Received: 14-08-2019, Accepted: 29-11-2019, Published online: 09-01-2020

doi: www.doi.org/10.14202/vetworld.2020.47-53 How to cite this article: Aisiah S, Prajitno A, Maftuch M, Yuniarti A (2020) Effect of Nauclea subdita (Korth.) Steud. leaf extract on hematological and histopathological changes in liver and kidney of striped catfish infected by Aeromonas hydrophila, Veterinary World, 13(1): 47-53.

\begin{abstract}
Aim: The present study was conducted to investigate the efficacy of different doses of Bangkal (Nauclea subdita) leaf extract on hematological and histological changes in kidney and liver of catfish (Pangasius hypophthalmus) infected by Aeromonas hydrophila.

Materials and Methods: Catfish were experimentally infected with A. hydrophila at a dose of $10^{8}$ cells $/ \mathrm{mL}$ through intraperitoneal injection, and the hematological and histological changes in the kidney and liver of catfish against the pathogen were observed.

Results: Not all concentrations of $N$. subdita caused a toxic effect in striped catfish. The clinical symptoms of catfish after infection with $A$. hydrophila and treatment with $N$. subdita leaf extract included morphological and behavioral changes. $N$. subdita leaf extract reduced mortality caused by $A$. hydrophila. Treatment with $N$. subdita leaf extract was effective in reducing the inflammation by decreasing the activity of neutrophils, monocytes, and lymphocytes. The Hb and Ht levels of catfish significantly decreased after exposure to $10^{8}$ cells $/ \mathrm{mL}$ of $A$. hydrophila and increased significantly after $N$. subdita treatment. Necrosis percentages in the kidney and liver also decrease after $N$. subdita treatment.
\end{abstract}

Conclusion: The results indicate that $N$. subdita leaf extract stimulates the immunity and increases the resistance of catfish to A. hydrophila. N. subdita leaf extract may be used as a potential source for future drug development and food applications.

Keywords: Aeromonas hydrophila, hematology, histopathology, Nauclea subdita.

\section{Introduction}

Fish farming in Indonesia, especially in South Kalimantan, is growing rapidly as a result of the increasing demand for fish. Catfish (Pangasius hypophthalmus) are a popular freshwater fish that are easily cultivated under marginal conditions. Intensive aquaculture with high stocking capacity can cause a decrease in environmental quality, making fish susceptible to diseases [1]. Fish experiencing diseases and stress due to environmental degradation die quickly by a lack of oxygen. Environmental degradation also allows the development and growth of pathogenic organisms [2-4]. Infectious diseases caused by bacteria are a severe problem in fish farming. Motile Aeromonas septicemia (MAS) or red spot disease is an infectious disease caused by Aeromonas hydrophila and often occurs in carp, catfish, and tilapia. MAS

Copyright: Aisiah, et al. Open Access. This article is distributed under the terms of the Creative Commons Attribution 4.0 International License (http://creativecommons.org/licenses/by/4.0/), which permits unrestricted use, distribution, and reproduction in any medium, provided you give appropriate credit to the original author(s) and the source, provide a link to the Creative Commons license, and indicate if changes were made. The Creative Commons Public Domain Dedication waiver (http://creativecommons.org/ publicdomain/zero/1.0/) applies to the data made available in this article, unless otherwise stated. attack on a fish stock is often catastrophic as it can kill fish seeds with mortality rates reaching $80-100 \%$ within 1-2 weeks [5]. The pathogen also spreads rapidly in high stocking densities [6]. The epidemic disease caused by $A$. hydrophila often occurs during the transition from the dry season to the rainy season.

A typical treatment to control MAS is the use of chemicals or antibiotics, but this creates bacterial resistance to antibiotics if used continuously. Another negative impact is the accumulation of these antibiotics in tissues, especially bone tissue, which poses health risks to consumers [7]. Drug and synthetic antibiotic residues accumulate in fish meat, kill non-target organisms, result in antibiotic drug resistance, affect fish growth and reproductive ability, and cause environmental pollution. Therefore, an alternative such as the bioactive compounds from plants with natural antibacterial properties is needed to control the disease in a safe and environmental-friendly manner.

Nauclea subdita (Korth.) Steud. is a semiaquatic plant that grows in a wetland, Kalimantan, Indonesia [8]. The active compounds such as phenolics, saponins, tannins, and alkaloids in the plant potentially eliminate pathogenic bacteria [9]. The inhibition zone created by the skin and leaves is larger than for 
the other parts of the plant. However, these studies are limited in simple extraction, thus the obtained results do not significantly contribute to both knowledge and society.

This study aimed to analyze the effectiveness of the bioactive compounds of Bangkal ( $N$. subdita) (Korth.) Steud. as a natural bactericide for controlling A. hydrophila in catfish aquaculture.

\section{Materials and Methods}

\section{Ethical approval}

This study was approved by the Animal Care and Use Committee, Brawijaya University, Malang, Indonesia (approval no. 940-KEP-UB).

\section{Research design}

A total of 15 adult catfish (P. hypophthalmus) were used in this study. Healthy catfish seeds (length 10-12 cm) were procured from the Mojokerto Fish Seed Center. Before the experimental tests, the fish were acclimatized for 7-10 days in a maintenance media (15 L capacity) under laboratory conditions. A completely randomized design with five treatment groups was used in this study, and each treatment was repeated 3 times:

$\mathrm{K}=$ Healthy fish without $A$. hydrophila infection

$\mathrm{A}=$ Fish with $A$. hydrophila infection without treatment

$\mathrm{B}=$ Fish with $A$. hydrophila infection and an N. subdita leaf extract dose of $50 \mathrm{mg} / \mathrm{L}$

$\mathrm{C}=$ Fish with $A$. hydrophila infection and an N. subdita leaf extract dose of $100 \mathrm{mg} / \mathrm{L}$

$\mathrm{D}=$ Fish with A. hydrophila infection and an N. subdita leaf extract dose of $150 \mathrm{mg} / \mathrm{L}$.

\section{Toxicity study of $\boldsymbol{N}$. subdita leaf extract}

Five fish seeds were placed into five research containers with $10 \mathrm{~L}$ of water. Then, $N$. subdita leaf extract was added into each container with the following concentration: $62.5 \mathrm{mg} / \mathrm{L}, 125 \mathrm{mg} / \mathrm{L}, 250 \mathrm{mg} / \mathrm{L}$, $500 \mathrm{mg} / \mathrm{L}$, and $1000 \mathrm{mg} / \mathrm{L}$. For each concentration, three replicates were maintained. The mortality of fish was observed every $12 \mathrm{~h}$ for $96 \mathrm{~h}$, and the concentration resulting in $50 \%$ mortality was determined as the lethal dose $\left(\mathrm{LD}_{50}\right)$.

\section{Pathogenicity study of $\boldsymbol{A}$. hydrophila}

For the pathogenicity test, five catfish were introduced into five research containers with $10 \mathrm{~L}$ water, and $A$. hydrophila was added into each container with the following densities: $10^{6}$ cells $/ \mathrm{mL}, 10^{7}$ cells $/ \mathrm{mL}$, $10^{8}$ cells $/ \mathrm{mL}, 10^{9}$ cells $/ \mathrm{mL}$, and $10^{10}$ cells $/ \mathrm{mL}$. The survival rate of the fish was recorded after $24 \mathrm{~h}$, and $\mathrm{LD}_{50}$ was determined.

\section{Lethal toxicity test and $\boldsymbol{N}$. subdita treatment}

Ten fish were placed into 10 research containers, and a suspension of $A$. hydrophila was added to five experimental containers. The symptoms of infection were observed, and after 24-36 h, N. subdita leaf extract was added in different treatment doses of $50 \mathrm{mg} / \mathrm{L}, 100 \mathrm{mg} / \mathrm{L}$, and $150 \mathrm{mg} / \mathrm{L}$ [10].
The observations and measurements were carried out every $24 \mathrm{~h}$. The mortality rate of the fish was determined at the end of the study. Water quality parameters including temperature, $\mathrm{pH}$, and dissolved oxygen were recorded at the beginning and end of the study.

\section{Blood sample collection}

Blood was collected from the control and treated groups using a microhematocrit. The collected blood was added to a $1 \mathrm{~mL}$ tube, which already included an anticoagulant, and $\mathrm{Hb}$, red blood cells, and white blood cells were measured. The remaining blood samples were centrifuged at $12,000 \mathrm{rpm}$ for $5 \mathrm{~min}$.

\section{Hematological analysis}

RBC and WBC were counted by a hemocytometer. The $\mathrm{Hb}$ concentration was measured using the Bijanti method (Bijanti, 2005). Erythrocytes were calculated according to the standard formula:

$$
\begin{aligned}
& \begin{array}{l}
\sum \text { Erytrocytes } \\
\left(\text { cells } / \mathrm{mm}^{3}\right)
\end{array}=N \times \frac{1}{5 \text { area } \times 1 / 250} \times 50 \\
& \begin{array}{l}
\sum \text { Leukocytes } \\
\left(\text { cells } / \mathrm{mm}^{3}\right)
\end{array}=N \times \frac{1}{4 \text { area } \times 0.1} \times 50
\end{aligned}
$$

\section{Leukocytes differentiation}

The differentiation of leukocytes was analyzed in blood smears stained with $10 \%$ Giemsa and observed under a microscope with $100 \times$. The type of leukocytes was determined and calculated until a total of 100 cells were counted.

\section{Histopathological analysis}

At the end of the experiment, three fish from each group were sampled after $96 \mathrm{~h}$ of exposure for histological analysis. The treated fish were killed and dissected to collect the kidney and liver. The organs were fixed in 10\% formalin and prepared for Hematoxylin-Eosin (H\&E) staining [11]. The stained slide was observed under a light microscope at $400 \times$.

\section{Statistical analysis}

The data were statistically analyzed at $p<0.05$ and significance was calculated by an analysis of variance test using SPSS for Windows.

\section{Results and Discussion}

\section{Toxicity test of $\boldsymbol{N}$. subdita leaf extract}

The toxicity test of $N$. subdita to P. hypophthalmus did not result in dead fish in any of the experimental groups. The survival rate of fish was higher than $92 \%$ under the administration of $N$. subdita at any dose (Figure-1). It was concluded that $N$. subdita had no toxic effect on striped catfish at any dose concentrations.

\section{Pathogenicity test of A. hydrophila}

The pathogenicity of $A$. hydrophila to catfish was determined by $100 \%$ mortality at a dose of $1 \times 10^{10}$ cells $/ \mathrm{mL}$ after $48 \mathrm{~h}$ and $1 \times 10^{9}$ cells $/ \mathrm{mL}$ after 
$96 \mathrm{~h}$. It was concluded that catfish were susceptible to $A$. hydrophila at doses of $1 \times 10^{9}$ cells $/ \mathrm{mL}$ and $1 \times 10^{10}$ cells $/ \mathrm{mL}$, resulting in redness of skin and slow movements (Table-1).

\section{Clinical signs after $\boldsymbol{N}$. subdita treatment}

A dose of $1 \times 10^{8}$ cells $/ \mathrm{mL}$ of $A$. hydrophila was used for the survival test to infect the striped catfish for $96 \mathrm{~h}$. After $24 \mathrm{~h}$ of treatment with N. subdita, clinical signs appeared in the treated fish (Table-2). The results were consistent with those of Abdelhamed et al. [12], where clinical signs were present $24 \mathrm{~h}$ after

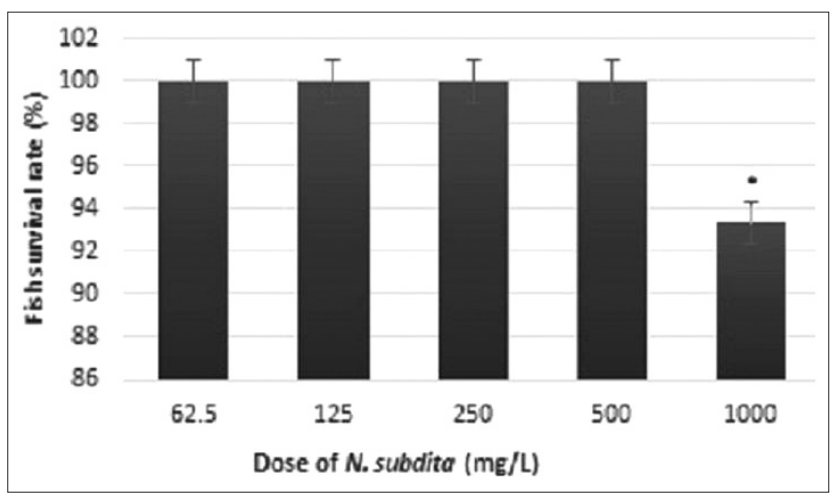

Figure-1: Average of survival rate of catfish with Nauclea subdita leaf extract treatment.
A. hydrophila infection until few days after infection, depending on the size and immunity of the fish. In another study, the clinical signs appeared $6 \mathrm{~h}$ after infection with $A$. hydrophila [13].

Clinical symptoms after infection included empty intestines, changes in body color, erroneous swimming behavior, reddish-colored tails, and jagged caudal fin [14] (Table-2). The catfish showed morphological and behavioral changes after infection with $A$. hydrophila and treatment with $N$. subdita leaf extract. The symptoms appeared $24 \mathrm{~h}$ after infection with $A$. hydrophila by the immersion method.

The results showed that $N$. subdita leaf extract could reduce the mortality caused by the $A$. hydrophila-induced MAS disease. The active compounds in $N$. subdita leaves are flavonoids, saponins, tannins, and triterpenoids based on phytochemical tests. According to the previous studies, these compounds have antibacterial properties inhibiting bacterial growth. No dead fish were found in this study after $N$. subdita leaf extract treatment, which might be a result of the phenolic and flavonoid compounds acting as an antioxidant. The phenolic compounds contribute to the oxidative mechanism by degrading reactive oxygen species. Antioxidants decrease oxidative

Table-1: The pathogenicity test of $A$. hydrophila to catfish ( $P$. hypophthalmus).

\begin{tabular}{|c|c|c|c|c|c|c|c|}
\hline \multirow[t]{2}{*}{ Density } & \multirow{2}{*}{$\begin{array}{l}\text { Number } \\
\text { of fish }\end{array}$} & \multicolumn{6}{|c|}{ Observation } \\
\hline & & $\mathbf{O} \mathbf{h}$ & $12 \mathrm{~h}$ & $24 \mathrm{~h}$ & $48 h$ & $72 \mathrm{~h}$ & $96 \mathrm{~h}$ \\
\hline $10^{6}$ & 5 & Normal & Normal & Decreased appetite & Mouth and tail redness & Flickertail & One fish dead \\
\hline $10^{7}$ & 5 & Normal & Normal & Decreased appetite & Flickertail & Two fishes dead & - \\
\hline $10^{8}$ & 5 & Normal & Not active & Flickertail & One fish dead & Two fishes dead & Three fishes dead \\
\hline $10^{9}$ & 5 & Normal & Not active & Two fishes dead & Three fishes dead & Four fishes dead & Five fishes dead \\
\hline $10^{10}$ & 5 & Normal & Skin redness & Four fishes dead & Five fishes dead & - & - \\
\hline Control & 5 & Normal & Normal & Normal & Normal & Normal & Normal \\
\hline
\end{tabular}

A. hydrophila=Aeromonas hydrophila, P. hypophthalmus=Pangasius hypophthalmus

Table-2: The clinical signs of catfish after $A$. hydrophila infection and $N$. subdita treatment.

Time Symptoms

\begin{tabular}{|c|c|c|}
\hline & A. hydrophila-infected fish with $N$. subdita treatment & A. hydrophila-infected fish \\
\hline $12 \mathrm{~h}$ & $\begin{array}{l}\text { Disturbed balance, swimming abnormalities, swimming } \\
\text { slowly, disturbed eating response }\end{array}$ & $\begin{array}{l}\text { Disturbed balance, swimming abnormalities, } \\
\text { swimming slowly, disturbed eating response }\end{array}$ \\
\hline $24 \mathrm{~h}$ & No eating response, sluggish movement & No eating response, sluggish movement \\
\hline $36 \mathrm{~h}$ & $\begin{array}{l}\text { No eating response, sluggish movement, some fish fin } \\
\text { start to swell and jagged }\end{array}$ & $\begin{array}{l}\text { No eating response, sluggish movement, some } \\
\text { fish fin are jagged }\end{array}$ \\
\hline 2 days & Jagged fin look more clearly, suffering from dropsy & $\begin{array}{l}\text { Three fish with inflammation and jagged fin were } \\
\text { dead, three dropsy fish were dead and some } \\
\text { of fish still dropsy, refusing food and sluggish } \\
\text { movement }\end{array}$ \\
\hline 3 days & $\begin{array}{l}\text { Inflammation and jagged fin, dropsy were observed, but } \\
\text { fish start to eat and active movement }\end{array}$ & $\begin{array}{l}\text { Two inflammation fish were dead and three } \\
\text { dropsy fish were dead, the low of eating response }\end{array}$ \\
\hline 4 days & $\begin{array}{l}\text { Inflammation starts to diminish, dropsy cured, swimming } \\
\text { in a normal and active }\end{array}$ & $\begin{array}{l}\text { Three hemorrhagic fish were dead, two dropsy } \\
\text { fish died, no response to feeding and slow } \\
\text { movement }\end{array}$ \\
\hline 5 days & $\begin{array}{l}\text { Inflammation gets smaller, normal swimming with active } \\
\text { movement, and response to feed is good }\end{array}$ & The slow movement, one hemorrhagic fish dies \\
\hline 6 days & $\begin{array}{l}\text { No more inflammation, active swimming, good response } \\
\text { to feed }\end{array}$ & $\begin{array}{l}\text { Not an active movement, no eating response, and } \\
\text { fish still hemorrhagic }\end{array}$ \\
\hline 7 days & $\begin{array}{l}\text { No more inflammation, active swimming, good response } \\
\text { to feed }\end{array}$ & $\begin{array}{l}\text { Not an active movement, no eating response, and } \\
\text { fish still hemorrhagic }\end{array}$ \\
\hline
\end{tabular}

A. hydrophila=Aeromonas hydrophila, N. subdita=Nauclea subdita 
stress and may be used as a supplement to prevent the disease [15].

\section{Leukocyte differentiation}

The results of the study showed that the neutrophil level was significantly increased (2.42\%) after A. hydrophila infection compared to healthy fish $(0.38 \%)$ (Figure-2a). After treatment with $N$. subdita leaf extract, the level of neutrophils significantly decreased at all dose concentrations. However, the lowest level of neutrophils was found after an N. subdita treatment $(1.388 \%)$ with a dose of $100 \mathrm{mg} / \mathrm{L}$ followed by treatments with a dose of $50 \mathrm{mg} / \mathrm{L}(1.47 \%)$ and $150 \mathrm{mg} / \mathrm{L}(2.08 \%)$. The increase in neutrophils contributed to the antimicrobial activity. Neutrophils in the blood increase after infection and act as the first defense in the body [16]. According to Sahan et al. [17], neutrophils play a role in defense against bacterial infections and migrate to blood vessels in the presence of inflammatory stimulation.

The level of monocytes after $N$. subdita treatment was also significantly decreased at all dose concentrations $(18.38 \%, 18.37 \%$, and $17.15 \%)(\mathrm{p}<0.05)$ compared to infected fish (22.44\%) (Figure-2b). The lowest level of monocytes was found at a dose of $100 \mathrm{mg} / \mathrm{L}$. Monocytes are the precursor of macrophages, which are involved in defense against bacterial infection through phagocytic mechanisms [2]. The level of lymphocytes decreased significantly (75.14\%) after infection with $A$. hydrophila compared to the healthy fish $(90.30 \%)$ by transforming into B-cells and producing antibodies to eliminate the bacteria [18].

Administration of $N$. subdita leaf extract to the infected fish caused an increase in the percentage of lymphocyte at all dose concentrations $(80.17 \%$, $80.24 \%$, and $80.78 \%$ ) (Figure-2). The increase in leukocytes resulted from the activation of neutrophils, monocytes, and lymphocytes to eliminate the bacteria through several mechanisms. This study showed that treatment with $N$. subdita leaf extract was effective in reducing the inflammation by decreasing the activation of neutrophils, monocytes, and lymphocytes.

\section{Hematological parameters}

$\mathrm{The} \mathrm{Hb}$ and $\mathrm{Ht}$ of catfish significantly decreased after exposure to sublethal concentrations of A. hydrophila $\left(10^{8}\right.$ cells $\left./ \mathrm{mL}\right)(7.63 \mathrm{mg} / \mathrm{dl})$ compared to healthy fish $(9.40 \mathrm{mg} / \mathrm{dl})$ (Table-3). The average $\mathrm{Hb}$ level in the experimental fish ranged between 9.30 and $10.33 \mathrm{mg} / \mathrm{dl}$, while the average $\mathrm{Hb}$ level in catfish is around $9.40 \mathrm{mg} / \mathrm{dl}$. The $\mathrm{Hb}$ value increased significantly $(\mathrm{p}<0.05)$ after $N$. subdita leaf extract treatment compared to A. hydrophila-infected fish. The increase in $\mathrm{Hb}$ was found for all dose concentrations in the $N$. subdita treatment, and the highest level of $\mathrm{Hb}$ was found for a dose of $100 \mathrm{mg} / \mathrm{L}$ of $N$. subdita.

There was a decrease in hemoglobin in treated fish due to competition for oxygen between the fish and the pathogen: The level of hemoglobin in fish varies with fish species, blood $\mathrm{pH}$, environmental conditions, and oxygen partial pressure [19]. Hb is involved in the catabolism process to produce energy by binding oxygen. The oxygen-binding ability of blood depends on the level of hemoglobin contained in the erythrocytes. Hidayat et al. [20] reported that low $\mathrm{Hb}$ levels caused a decrease in the metabolism rate and energy production. Therefore, low $\mathrm{Hb}$ levels made some fish move slowly and have no eating response. This clinical sign can be observed $12 \mathrm{~h}$ after infection with $A$. hydrophila in catfish (Table-2).

The results showed that after A. hydrophila infection, the level of $\mathrm{Ht}$ was significantly decreased

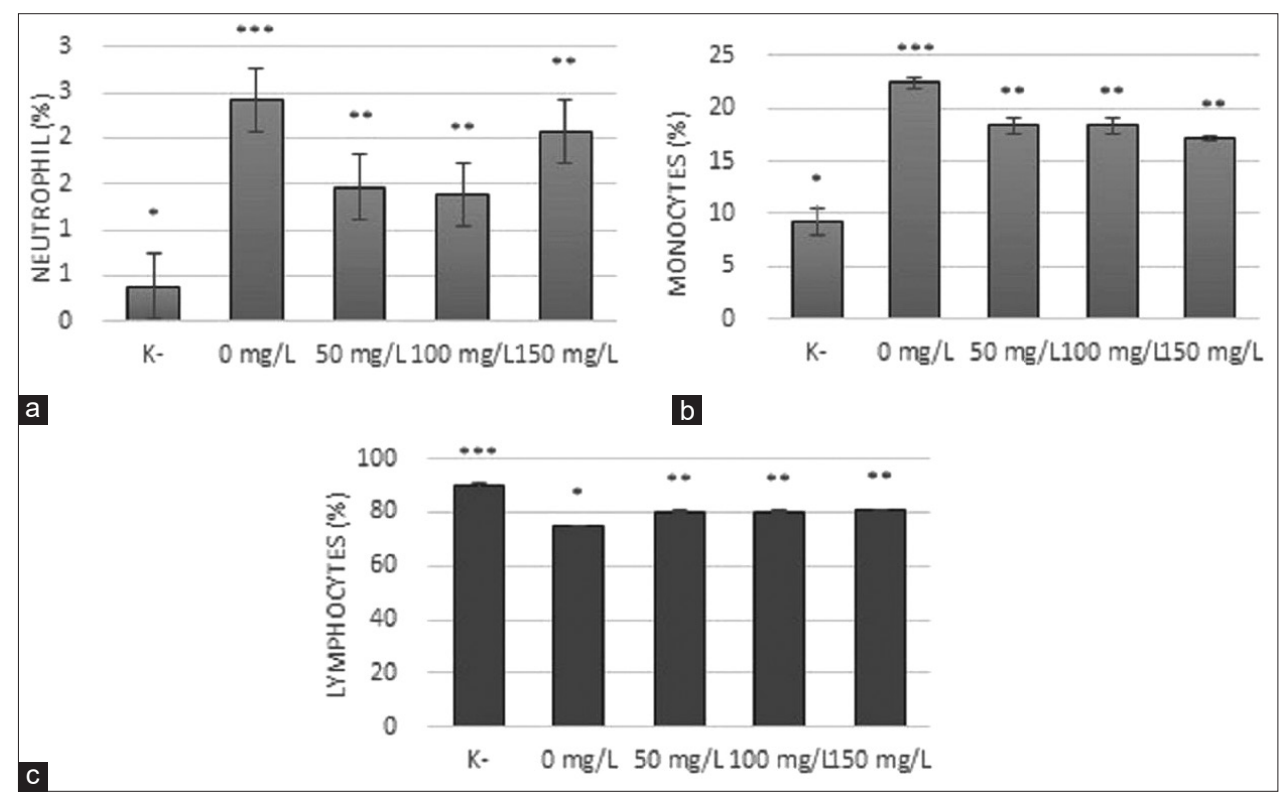

Figure-2: The level of (a) neutrophil, (b) monocytes, and (c) lymphocytes after Nauclea subdita leaf extract treatment in Aeromonas hydrophila-treated striped catfish. $\mathrm{K}^{-}=$Healthy fish; $0 \mathrm{mg} / \mathrm{L}=$ Infected fish without treatment; $50 \mathrm{mg} / \mathrm{L}=\mathrm{Infected}$ fish and administration of $50 \mathrm{mg} / \mathrm{L}$ of $N$. subdita leaf extract; $100 \mathrm{mg} / \mathrm{L}=$ Infected fish and administration of $100 \mathrm{mg} / \mathrm{L}$ of N. subdita leaf extract; $150 \mathrm{mg} / \mathrm{L}$ : Infected fish and administration of $150 \mathrm{mg} / \mathrm{L}$ of $\mathrm{N}$. subdita leaf extract. 
Table-3: The hematological parameter observed after N. subdita treatment in A. hydrophila-infected catfish.

\begin{tabular}{lccccc}
\hline Hematological parameters & \multicolumn{4}{c}{ Group treatment } \\
\cline { 2 - 6 } & Healthy fish & Infected fish & $\mathbf{5 0} \mathbf{~ m g / L}$ & $\mathbf{1 0 0} \mathbf{~ m g / L}$ & $\mathbf{1 5 0} \mathbf{~ m g} / \mathbf{L}$ \\
\hline $\mathrm{Hb}(\mathrm{g} / 100 \mathrm{~mL})$ & $9.40^{\mathrm{b}}$ & $7.63^{\mathrm{a}}$ & $9.3^{\mathrm{c}}$ & $10.33^{\mathrm{d}}$ & $9.30^{\mathrm{c}}$ \\
$\mathrm{Ht}(\%)$ & $26.67^{\mathrm{b}}$ & $21.33^{\mathrm{a}}$ & $24.33^{\mathrm{c}}$ & $26.33^{\mathrm{d}}$ & $25.00^{\mathrm{c}}$ \\
\hline
\end{tabular}

$\mathrm{a}, \mathrm{b}, \mathrm{c}, \mathrm{d}$ Values in rows denoted with different letter differ significantly at $\mathrm{p}<0.05$. A. hydrophila=Aeromonas hydrophila, N. subdita=Nauclea subdita

Table-4: Blood plasma color in fish.

\begin{tabular}{llll}
\hline $\begin{array}{l}\text { Treatment } \\
(\mathbf{m g} / \mathbf{L})\end{array}$ & \multicolumn{3}{c}{ Sampling } \\
\cline { 2 - 4 } & $\mathbf{1}$ & $\mathbf{2}$ & $\mathbf{3}$ \\
\hline $\mathrm{K}$ & Clear white & Clear white & Clear white \\
0 & Clear white & Yellowish clear & Reddish clear \\
50 & Clear white & Yellowish clear & Reddish clear \\
100 & Clear white & Yellowish clear & Yellowish clear \\
150 & Clear white & Yellowish clear & Yellowish clear \\
\hline
\end{tabular}

compared to healthy fish ( $26.67 \%$ vs. $21.33 \%)$. A dose of $100 \mathrm{mg} / \mathrm{mL} \mathrm{N}$. subdita resulted in the highest level of $\mathrm{Ht}(26.33 \%)$ compared to the other dose concentrations $(50 \mathrm{mg} / \mathrm{mL}=24.33 \% ; 150 \mathrm{mg} / \mathrm{mL}=25 \%)$ (Table-3). The hematocrit level varies with nutritional factors, age, sex, body size, and spawning period. Hematocrit can be used as a parameter to determine the health status and abnormalities of fish. According to Shen et al. [21], the level of Ht in Teleostei fish ranges from 20 to $40 \%$. A hematocrit level of $<22 \%$ will lead to anemia in fish. Anemia has an impact on fish metabolism and growth as the low number of erythrocytes results in reduced nutrient supply to the cells, tissues, and organs [16]. The increase in Ht after $N$. subdita treatment indicated that the health status of the infected fish also increased.

According to Table 4, the blood plasma of healthy fish was usually clear white or clear yellowish. The blood plasma in the treated fish was reddish clear, which indicated the presence of hemolysis caused by $A$. hydrophila infection, as demonstrated by Mastan [22].

\section{Histopathological changes on liver and kidney}

The results suggest that $A$. hydrophila infection increased hepatic necrosis significantly $(\mathrm{p}<0.05)$ in infected catfish compared to healthy fish. N. subdita leaf extract treatment decreases the hepatic necrosis significantly $(\mathrm{p}<0.05)$ compared to infected fish (Figure-3).

Hepatic tissue infected with $A$. hydrophila showed necrosis and swelling of hepatic cells, characterized by the presence of vacuoles. Cell swelling occurs due to an unbalance in electrolytes between the inner and outer cells [23]. The cells pumping fluid outward cause an inward movement of extracellular fluid; meanwhile, the cells lose their ability to pump sodium ions. As a result, the cells will lose their integrity, leading to cell death (necrosis). Cell swelling will diminish if the bacterial infection disappears. However, the cell cannot tolerate the damage caused by a prolonged infection and will undergo necrosis [24].

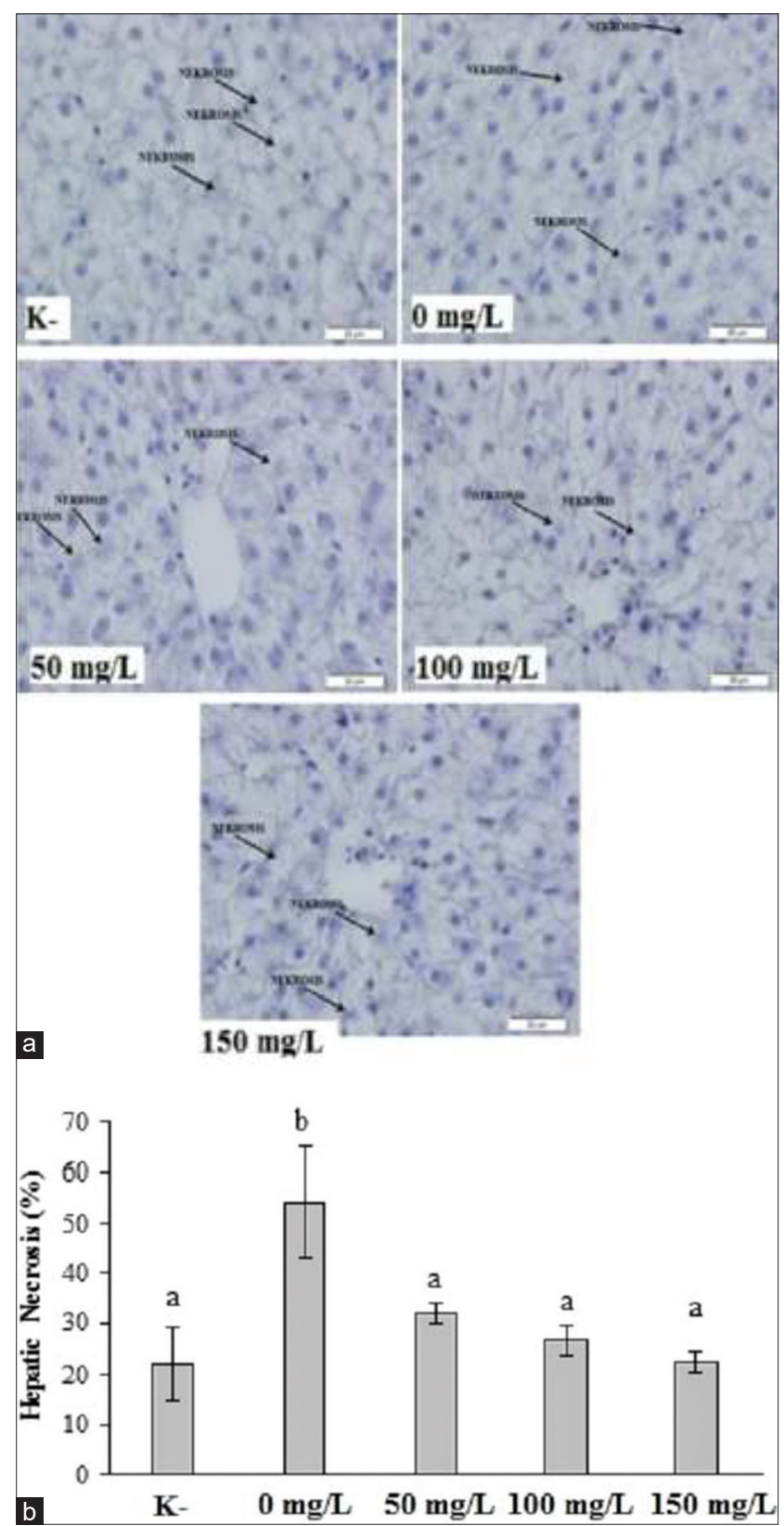

Figure-3: Histopathology overview in healthy striped catfish and striped catfish challenged with Aeromonas hydrophila with/without Nauclea subdita treatment. (a) Hepatic section of striped catfish at $100 \times$ and (b) hepatic necrosis was represented as mean \pm standard deviation. The different letter on the chart considered as significantly different for each group at $p<0.05$ based on the Tukey test as a post hoc test. $\mathrm{K}^{-}=$Healthy fish; $0 \mathrm{mg} / \mathrm{L}=$ Infected fish without treatment; $50 \mathrm{mg} / \mathrm{L}=$ Infected fish and administration of $50 \mathrm{mg} / \mathrm{L}$ of $N$. subdita leaf extract; $100 \mathrm{mg} / \mathrm{L}=$ Infected fish and administration of $100 \mathrm{mg} / \mathrm{L}$ of $N$. subdita leaf extract; $150 \mathrm{mg} / \mathrm{L}=$ Infected fish and administration of $150 \mathrm{mg} / \mathrm{L}$ of $N$. subdita leaf extract). 
A. hydrophila infection increased kidney necrosis significantly $(\mathrm{p}<0.05)$ in Pangasius fish compared to healthy fish. $N$. subdita leaf extract treatment decreases the kidney necrosis significantly $(\mathrm{p}<0.05)$ compared to infected fish (Figure-4).

The kidney necrosis is caused by swollen epithelial cells in the renal tubules, triggering glomerulus proliferation followed by lysis in the Bowman capsule. Kidneys are the excretory organs and thus susceptible to pathogens. The kidneys have two main functions: Excreting most of the final metabolic products and regulating the body fluid concentration [25].

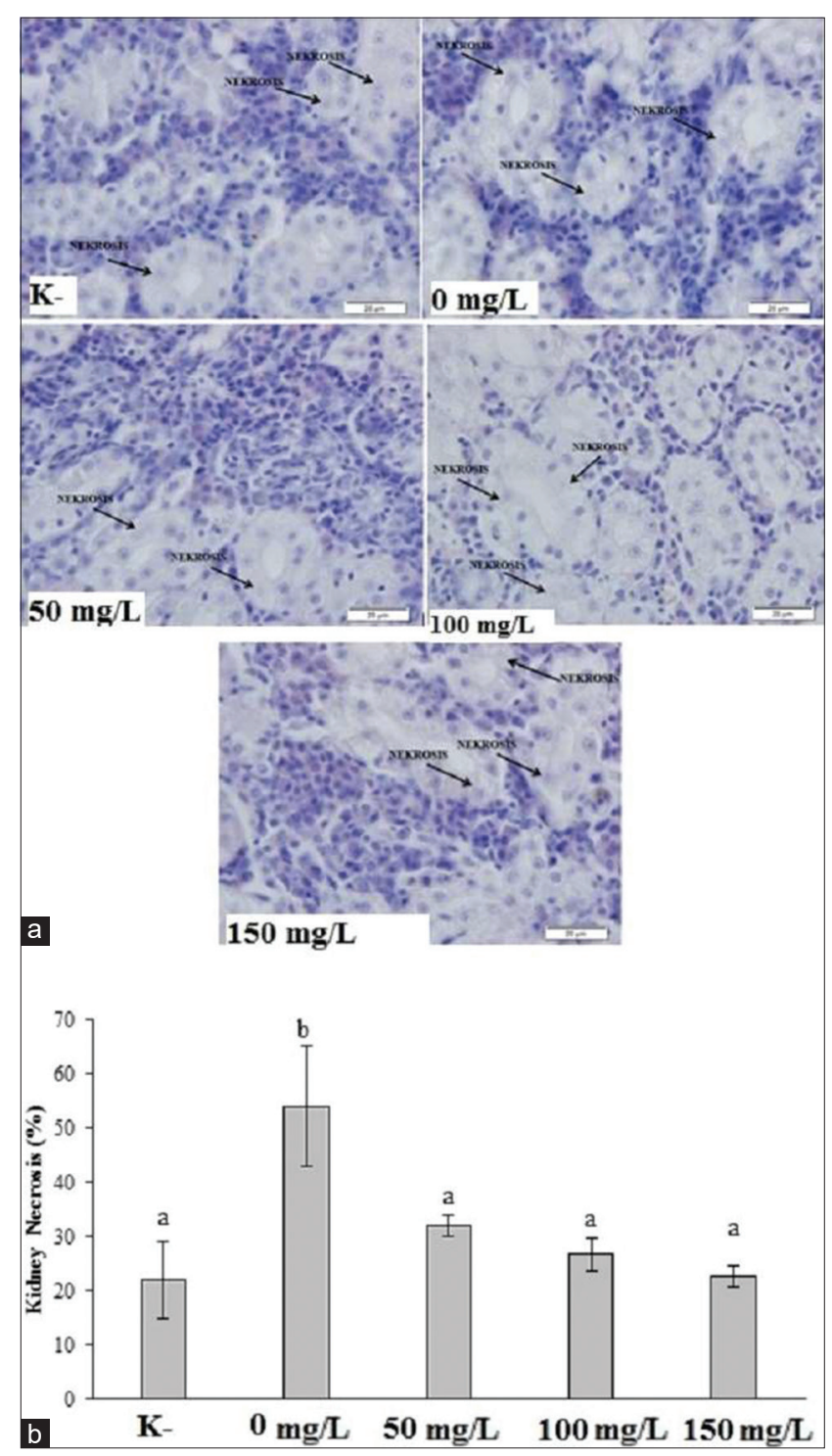

Figure-4: Histopathology overview in healthy striped catfish and striped catfish challenged with Aeromonas hydrophila with/without Nauclea subdita treatment. (a) Kidney section of striped catfish at $100 \times$ and (b) kidney necrosis was represented as mean \pm standard deviation. The different letter on the chart considered as significantly different for each group at $\mathrm{p}<0.05$ based on the Tukey test as a post hoc test. $\mathrm{K}^{-}=$Healthy fish; $0 \mathrm{mg} / \mathrm{L}=$ Infected fish without treatment; $50 \mathrm{mg} / \mathrm{L}=$ Infected fish and administration of $50 \mathrm{mg} / \mathrm{L}$ of $N$. subdita leaf extract; $100 \mathrm{mg} / \mathrm{L}=$ Infected fish and administration of $100 \mathrm{mg} / \mathrm{L}$ of $N$. subdita leaf extract; $150 \mathrm{mg} / \mathrm{L}=$ Infected fish and administration of $150 \mathrm{mg} / \mathrm{L}$ of N. subdita leaf extract
$N$. subdita contains secondary metabolites such as tannins, alkaloids, and phenolic compounds, which act as a natural bactericide [26]. The leaves, bark, and root of Nauclea latifolia, N. subdita, and Nauclea officinalis are also known to contain alkaloids, flavonoids, and tannins [27-29]. Some phytochemicals such as tannins, alkaloids, and flavonoids are proven to have antibacterial properties in fish [30].

The methanolic extract of the bark and leaves of Nauclea obversifolia demonstrated a higher antibacterial effect, suggesting that fractionation increases the antibacterial activity of bark and skin root. The ethyl acetate fraction was most effective in inhibiting bacterial growth [31]. The extract of the $N$. latifolia root is more effective than the bark and leaf extract [32]. Plant extract contains active compounds that mimic synthetic drugs in in vitro studies [33]. Tannins perform as a bacteriostatic and a bactericide against pathogenic bacteria, including A. hydrophila, Escherichia coli, Listeria, Pseudomonas, Salmonella, Staphylococcus, and Streptococcus [34].

Phytochemicals such as polyphenol are also expected to have an inhibitory effect on bacteria. Tannins have toxicity and inhibit some enzyme in microorganisms [35]. The $N$. latifolia extract contains polyphenol, an antioxidant and antibacterial compound fighting pathogens, such as Staphylococcus aureus, Streptococcus pyogenes, E. coli, and Candida [36].

\section{Conclusion}

The present study demonstrated that $N$. subdita leaf extract did not have a toxic effect on stripped catfish at $50 \mathrm{mg} / \mathrm{L}, 100 \mathrm{mg} / \mathrm{L}$, and $150 \mathrm{mg} / \mathrm{L}$ dose concentrations. Furthermore, N. subdita extract reduced the mortality and inflammation, increased the hemoglobin and hematocrit values, and improved kidney and liver necrosis after infection with $A$. hydrophila.

\section{Authors' Contributions}

SA contributed to the conception, research design, and designed manuscripts. AP did data acquisition. MM did analysis and/or interpretation of data. AY improved the manuscript. All authors read and approved the final manuscript.

\section{Acknowledgments}

The authors would like to appreciate thanks to the Ministry of Research, Technology and Higher Education, Indonesia for providing BPPDN scholarship in 2014 and research dissertation doctoral grants in 2018 (No. 040/UN8.2/PL/2018) and Brawijaya University, Indonesia for providing facilities for the research.

\section{Competing Interests}

The authors declare that they have no competing interests.

\section{Publisher's Note}

Veterinary World remains neutral with regard to jurisdictional claims in published institutional affiliation. 


\section{References}

1. Citterio, B. and Biavasco, F. (2015) Aeromonas hydrophila virulence. Virulence, 6(5): 417-418.

2. Duman, S. and Sahan, A. (2017) Determination of some hematological parameters and non-specific immune responses in Garra rufa (Heckel, 1843) living in Kangal (sivas) balikli çermik thermal hot spring and topardiç stream (sivas). J. Aquac. Eng. Fish. Res., 3(3): 108-115.

3. Hedayati, A. and Tarkhani, R. (2014) Hematological and gill histopathological changes in iridescent shark, Pangasius hypophthalmus (Sauvage, 1878) exposed to sublethal diazinon and deltamethrin concentrations. Fish Physiol. Biochem., 40(3): 715-720.

4. Peatman, E., Mohammed, H., Kirby, A., Shoemaker, C.A., Yildirim-Aksoy, M. and Beck, B.H. (2018) Mechanisms of pathogen virulence and host susceptibility in virulent Aeromonas hydrophila infections of channel catfish (Ictalurus punctatus). Aquaculture, 482(1): 1-8.

5. Thiyagarajan, P., Bhavani, A.L., Ebbie, M.G. and Chandra, G. (2014) A study on the control of Aeromonas hydrophila infection in the catfish by medicinal plants. Sch. Acad. J. Biosci., 2(2): 144-150.

6. Salosso, Y. (2018) Pemanfaatan Daun Miana yang Dicampur Madu dalam Pengobatan Ikan Mas (Cyprinus carpio) yang Terinfeksi Aeromonas hydropilla. Proceedings of Simposium Nasional Kelautan dan Perikanan. Vol. 5. p313-322.

7. Jiwantoro, F., Purwanta, M. and Yuani, S. (2017) UJI Efektivitas Ekstrak Bunga Kamboja (Plumeria alba) Sebagai Antibakteri Terhadap Streptococcus pyogenes. J. Kedokt. Syiah Kuala, 17(3): 147-151.

8. Thamrin, M., Asikin, S., Mukhlis, A. and Budiman, A. (2014) Potensi Ekstraktan Flora Lahan Rawa Sebagai Pestisida Nabati. Balittra, Bogor. p35-54.

9. Aisiah, S. (2012) Efikasi Ekstrak Mengkudu (Morinda citrifolia) terhadap bakteri Aeromonas hidrophila dan Toksisitasnya pada Ikan Nila (Oreochromis niloticus). Sains Akuatik, 14(1): 55-63.

10. Aisiah, S., Prajitno, A., Maftuch, M. and Yuniarti, A. (2019) The potential of bangkal leaf (Nauclea subdita [Korth.] Steud.) extract. AACL Bioflux, 12(6): 2093-2102.

11. Carella, F. and Sirri, R. (2017) Editorial: Fish and shellfish pathology. Front. Mar. Sci., 4: 375.

12. Abdelhamed, H., Ibrahim, I., Baumgartner, W., Lawrence, M.L. and Karsi, A. (2017) Characterization of histopathological and ultrastructural changes in channel catfish experimentally infected with virulent Aeromonas hydrophila. Front. Microbiol., 8: 1519.

13. Bebak, J., Wagner, B., Burnes, B. and Hanson, T. (2015) Farm size, seining practices, and salt use: Risk factors for Aeromonas hydrophila outbreaks in farm-raised catfish, Alabama, USA. Prev. Vet. Med., 118(1): 161-168.

14. Saranraj, P. and Sujitha, D. (2015) Mangrove medicinal plants: A review. Am. Eurasian J. Toxicol. Sci., 7(3): 146-156.

15. Gao, M. and Xiao, H. (2012) Activity-guided isolation of antioxidant compounds from Rhizophora apiculate. Molecules, 17(9): 10675-10682.

16. Sahan, A., Duman, S., Colak, S.O., Cinar, E. and Bilgin, R. (2017) Determination of some hematological and non-specific immune defences, oxidative stress and histopathological status in rainbow trout (Oncorhynchus mykiss) fed rosehip (Rosa canina) to Yersinia ruckeri. Turk. J. Fish. Aquat. Sci., 17(1): 91-100.

17. Ali, T.E., El-Sayed, A.M., Eissa, M.A.R. and Hanafi, H.M. (2018) Effects of dietary Biogen and sodium butyrate on hematological parameters, immune response, and histological characteristics of Nile tilapia (Oreochromis niloticus) fingerlings. Aquac. Int., 26(1): 139-150.

18. Grant, K.R. (2015) Fish hematology and associated disorders. Clin. Lab. Med., 35(3): 681-701.
19. Ye, L., Amberg, J., Chapman, D., Gaikowski, M. and Liu, W.T. (2016) Fish gut microbiota analysis differentiates physiology and behavior of invasive Asian carp and indigenous American fish. ISME J., 8(3): 541-551.

20. Hidayat, R., Harpeni, E. and Widaryanto. (2014) Profil hematologi kakap putih (Lates calcallifer) yang distimulasi dengan jintan hitam (Nigela sativa) dan efektifitasnya terhadap infeksi Vibrio alginolyticus. Aquac. Eng. Technol. J., 3(1): 327-334.

21. Shen, Y., Wang, D., Zhao, J. and Chen, X. (2018) Fish red blood cells express immune genes and responses. Aquac. Fish., 3(1): 14-21.

22. Mastan, S.A. (2015) Use of Immunostimulants in aquaculture disease management. Int. J. Fish. Aquat. Stud., 2(4): 227-280.

23. Benli, A.C., Koksal, G. and Ozkul, A. (2008) Sublethal ammonia exposure of Nile tilapia (Oreochromis niloticus L.): Effects on gill, liver and kidney histology. Chemosphere, 72(9): 1355-1358.

24. Camargo, M.M.P. and Martinez, C.B.R. (2007) Histopathology of gills, kidney and liver of a Neotropical fish caged in an urban stream. Neotrop. Ichthyol., 5(3): 327-336.

25. Panigoro, N., Bahnan, M., Prayudha, D.C. and Wakita, K.S. (2007) Teknik Dasar Histologi Dan Atlas Dasar Histopatologi Ikan. Balai Budidaya Air Tawar Jambi dan Japan International Cooperation Agenci, Jambi.

26. Ette, E.O., Ubulom, E.P.M., Ekpenyong, E.C., Ekong, S.U., Akpan, E.O. and Tambari, D.V. (2014) In vivo antiplasmodial activities of Nauclea latifolia. Asian J. Med. Sci., 6(3): 1-6.

27. Liew, S.Y., Khaw, K.Y., Murugaiyah, V., Looi, C.Y., Wong, Y.L., Mustafa, M.R., Litaudon, M. and Awang, K. (2015) Natural indole butyrylcholinesterase inhibitors from Nauclea officinalis. Phytomedicine, 22(1): 45-48.

28. Abbah, J., Amos, S., Chindo, B., Ngazal, I., Vongtau, H.O., Adzu, B., Farida, T., Odutola, A., Wambebe, C. and Gamaniel, K.S. (2010) Pharmacological evidence favoring the use of Nauclea latifolia in malaria ethnopharmacy: Effects against nociception, inflammation, and pyrexia in rats and mice. J. Ethnopharmacol., 127(1): 85-90.

29. Amos, S., Abbah, J., Chindo, B., Edmond, I., Binda, L., Adzu, B., Buhari, S., Odulata, A.A., Wambebe, C. and Gamaniel, K. (2005) Neuropharmacological effects of the aqueous extract of Nauclea latifolia root bark in rats and mice. J. Ethnopharmacol., 97(1): 53-57.

30. Haniffa, M.A. and Kavitha, K. (2012) Antibacterial activity of medicinal herbs against the fish pathogen Aeromonas hydrophila. J. Agric. Technol., 8(1): 205-211.

31. Seukep, J.A., Sandjo, L.P., Ngadjui, B.T. and Kuete, V. (2016) Antibacterial and antibiotic-resistance modifying activity of the extracts and compounds from Nauclea pobeguinii against Gram-negative multi-drug resistant phenotypes. BMC Complement. Alter. Med., 16(193): 1-8.

32. El-Mahmood, A., Doughari, J. and Chanji, F. (2008) In vitro antibacterial activities of crude extracts of Nauclea latifolia and Daniella oliveri. Sci. Res. Essay, 3(1): 102-105.

33. Lino, A. and Deogracious, O. (2006) The in vitro antibacterial activity of Annona senegalensis, Securidacca longipendiculata and Steganotaenia araliacea Ugandan medicinal plants. Afr. Health Sci., 6(1): 31-35.

34. Huang, Q., Liu, X., Zhao, G., Hu, T. and Wang, Y. (2018) Potential and challenges of tannins as an alternative to in-feed antibiotics for farm animal production. Anim. Nutr., 4(2): 137-150.

35. Mazzeo, M.F., Lippolis, R., Sorrentino, A., Liberti, S., Fragnito, F. and Siciliano, R.A. (2015) Lactobacillus acidophilus rutin interplay investigated by proteomics. PLoS One, 10(11): e0142376.

36. Okoro, I.O., Osagie, A. and Asibor, E.O. (2010) Antioxidant and antimicrobial activities of polyphenols from ethnomedicinal plants of Nigeria. Afr. J. Biotechnol., 9(20): 2989-2993. 